\title{
Plastination technology for anatomical studies in Nigeria: Opinion of teachers at medical institutions
}

\author{
Authors: \\ Onyemaechi O. Azu ${ }^{1}$ \\ Aniekan I. Peter ${ }^{2}$ \\ Aquaisua N. Aquaisua ${ }^{2}$ \\ Gabriel J. Ekandem²

\section{Affiliations:} \\ ${ }^{1}$ Discipline of Clinica \\ Anatomy, Nelson R Mandela \\ School of Medicine, \\ University of KwaZulu-Natal, \\ South Africa \\ ${ }^{2}$ Department of Anatomy, \\ Faculty of Basic Medical \\ Sciences, University of Uyo, \\ Nigeria
}

\section{Correspondence to: \\ Onyemaechi Azu}

Email:

azu@ukzn.ac.za

Postal address:

Private Bag X54001, Congella

4013, South Africa

\section{Dates:}

Received: 26 Mar. 2012

Accepted: 19 Nov. 2012

Published: 09 Apr. 2013

How to cite this article: Azu, O.O., Peter, A.I., Aquaisua, N.A. \& Ekandem, G.J., 2013, 'Plastination technology for anatomical studies in Nigeria: Opinion of teachers in medical institutions', Health SA Gesondheid, 18(1), Art. \#664, 6 pages, http://dx.doi. org/10.4102/hsag.v18i1.664

\section{Copyright:}

(C) 2013. The Authors.

Licensee: AOSIS

OpenJournals. This work

is licensed under the

Creative Commons

Attribution License.
Read online:
Dr. Gunther von Hagens developed plastination as a technique of tissue preservation in 1977. He used a delicate method of forced impregnation with curable polymers like silicone, epoxy or polyester resins for preservation of anatomical specimens. With plastination, every part of a biological tissue is treated, preserving it for educational purposes. Hence, there are vast applications in the medical field. We set out to survey the knowledge and opinion of lecturers of anatomy about plastinated specimen use in medical schools through the administration of questionnaires to respondents who participated at the Society of Experimental and Clinical Anatomists of Nigeria (SECAN) conference in 2011. It was found that $50.0 \%$ and $23.75 \%$ of respondents respectively, had their masters and doctorate degrees in Anatomy. Less than 8.0\% utilised plastination as a tool for teaching as against 40\% (plastic models), 36.25\% (cadavers) and $15.0 \%$ (pathology pots). Conventional methods such as fixation by immersion (15.0\%) and embalming (52.5\%) with formaldehyde were commonly used for long term preservation of tissues in their various institutions. These methods were found to be less costly $(25.0 \%)$, easy to use (56.25\%) and the only method (12.25\%) available, even though they posed some health hazards $(96.0 \%)$. Whilst only $6.25 \%$ of the respondents did not know anything about plastination, $93.75 \%$ were aware of it. The advocacy for preservation of tissues by plastination has been gradual in developed countries. We recommend the use of plastinates in medical schools in Nigeria.

Dr. Gunther von Hagens het in 1977 plastinering as 'n tegniek vir weefselbewaring ontwikkel. Hy gebruik ' $n$ delikate metode van gedwonge bevrugting met geneesbare polimere soos silikoon, epoksi of poliësterhars vir die behoud van anatomiese monsters. Met plastinering word elke deel van ' $n$ biologiese weefsel behandel, om dit vir opvoedkundige doeleindes te bewaar. Om die rede is daar wye toepassings in die mediese veld. Ons het ten doel gehad om die kennis en menings van dosente in anatomie in mediese skole oor plastineringsmonsters, aan te teken. Dit is gedoen deur die uitreiking van vraelyste aan respondente wat in 2011 'n konferensie van die Vereniging van Eksperimentele en Kliniese Anatomiste in Nigerië (SECAN) bygewoon het. Daar is bevind dat $50.0 \%$ en $23.75 \%$ van die respondente onderskeidelik beskik oor meesters- en doktorsgrade in Anatomie. Minder as $8.0 \%$ gebruik plastinering as ' $\mathrm{n}$ instrument vir onderrig teenoor $40 \%$ (plastiekmodelle), $36.25 \%$ (kadawers) en $15.0 \%$ (patologiepotte). Konvensionele metodes soos fiksasie deur onderdompeling (15.0\%) en balseming (52.5\%) met formaldehied word algemeen gebruik vir die langtermyn bewaring van weefsel in hul onderskeie instellings. Hierdie metodes is, na raming, goedkoper (25.0\%), en maklik om te gebruik. Slegs $6.25 \%$ van die respondente het geen kennis van plastinering gehad nie, terwyl $93.75 \%$ daarvan bewus was. Die gebruik van plastinering as preservering van weefsel groei geleidelike in ontwikkelde lande. Ons beveel die gebruik van plastinades in mediese skole in Nigerië aan.

\section{Introduction}

\section{Background}

Throughout the history of medicine the theme has been the quest for knowledge of the interior of the human body, and much of this knowledge has come from dissection of the human body. Today, modern techniques used to preserve the human body for didactic purposes are built on methods that began in the time of the Egyptian pharaohs where desiccation was the primary means of mummification in the Early Dynastic period. This same general technique was one of the first means used to preserve specimens for teaching, rather than religious purposes. Embalming solutions were later developed that were better able to preserve whole bodies (Saeed, Amin \& Saleh 2001). Anatomy, the science of human biology, is a major basic discipline every student or professional has to study when entering medicine or biomedical sciences. With the advent of new techniques and computer science, alternative methods of teaching anatomy have come 
into existence (Horst-Werner et al. 2008). This has greatly impacted on the delivery of the core content of anatomy to the various disciplines that are serviced directly from anatomical departments, but also on the training methodologies adopted for medical or dental training in general. However, there is the need for continued engagement and adaptation to the various modalities and not focus on determining the supremacy of one methodology over another.

A further advancement in preservation of the body was made through the replacement of the remaining fluids in an embalmed body (for example) with a polymer-a process called plastination (Latorre et al. 2007). This technique was invented in 1977 by Dr. Gunther von Hagens. Since its introduction, it has gained wide acceptance throughout the world (Von Hagens 1979) and has been used to great advantage as adjuncts in the dissecting lab and are considered today's milestone in medical education (Saeed et al. 2001). The potential value of plastination in research is increasingly being appreciated. Plastinated specimens are clean, dry, odourless and durable, real, biologic specimens that can be handled without gloves and do not require any special storage conditions or care. These specimens also prevent exposure of staff and students to the toxic substances (e.g. formaldehyde) used in classical preservation of biological tissues (Latorre et al. 2007; Azu et al. 2012).

The evaluation of teaching resources should be a systematic process of gathering, analysing, and interpreting reliable information. The evaluation should establish merit or value judgments that will lead to a generalised improvement in the selected teaching materials (Latorre et al. 2007) and also impact upon the expected outcomes of students. In this instance, plastinates are the teaching materials and hence represent a basic resource available to teachers of anatomy for teaching anatomical knowledge. Student satisfaction and acceptance has also been recorded using plastinated models or specimens (Latorre et al. 2007) and in our previous survey (Azu et al. 2012) these were also shown as an additional resource in anatomical laboratories. Nevertheless, plastinated specimens should ideally be used as adjuvant with cadaveric dissection for full appreciation of the interactions between body systems and to understand the body as one entity (Sugand et al. 2010).

As plastinates enter the academic arena, what are their advantages over the other preservation techniques? This is particularly relevant as the technique is yet to become fully integrated as a teaching resource in most of the medical schools across Africa and Nigeria in particular. Nigerian medical educational training is undergoing reforms to align with changing disease trends and societal issues afflicting the country. Some of these changes are directed towards curriculum amendments, modifications to accommodate increasingly higher pressures for greater number of intakes to medical institutions and/or adaptation of existing materials for learning to fall in-line with recent developments in the field of medicine. According to Jones (2002), those situated within anatomy departments and medical schools, the temptation to overlook educational issues in this broader sense is all too powerful.

Human anatomists dare not isolate themselves from the society in which they are located; they are heavily dependent upon public sentiment that condones and supports their activities. More so, as medical school curricula adapt to changes in the field of medicine, urgent reform to address obvious imbalances with counterpart medical schools abroad in areas of learning theory, new knowledge in educational methodologies and advances in technological developments becomes imperative for teachers of anatomy.

\section{Problem statement}

Medical education is unique amongst all other educational and professional disciplines because of its centrality towards patient care and life. As such, particular elements dealing with how doctors relate with the ever-changing society visà-vis professional codes of conduct that relate to specific methodologies of training, have been perceived to be deficient. Therefore, there is the need to address the present challenges by development of innovative approaches to teaching, learning and research.

The 21st century has presented both teachers and students the greatest challenge to date, with the significant influence of the information technology. This has placed an enormous burden on medical teachers and educators to adapt to the change in medical trends and to develop ways of delivering knowledge to students in a manner that are evidencebased and theoretically robust. We previously carried out a survey on the applicability and relevance of problem-based learning in anatomy for pharmacy students (Azu \& Osinubi 2011) and on the introduction and relevance of plastinates in anatomical resource centres (Azu et al. 2012) as part of this changing trend in medical education. Therefore, it has become more pertinent than ever to ask the question: what are the opinions of teachers of anatomy regarding the need to adapt to the newer teaching modalities such as the ProblemBased Learning method, use of plastinated specimens, computer-aided software and so forth, to teaching the subject of anatomy within the framework of the various institutions?

\section{Research purpose}

We set out to elicit the knowledge and awareness of the technique of plastination and its applications amongst anatomy lecturers in the various medical colleges in Nigeria.

\section{Definition of concepts}

Plastination: This is a method of preservation of cadavers and biological specimens keeping them fulsome, lifelike and indefinitely antiseptic (Saeed et al. 2001).

Anatomy: This is primarily the scientific study of the structure of the (human) body. Anatomy involves both the study of structures visible to the naked eyes (gross anatomy) 
as well as structures studied with the aid of a microscope (Gray 1918). In years gone by it was accepted that anatomy was principally involved with dissection of a body (human) or animal (veterinary), but these days the science of the study of the structure has evolved to include deformities or abnormalities, as well as development.

\section{Significance of the study}

The application of plastination technique as an added resource in anatomical education is of importance in the era of dwindling cadaveric materials for medical education globally and in African Medical settings in particular. Raising the advocacy for use of plastinates as adjunct to cadavers is needed to complement the learning and teaching of anatomy in medical schools.

\section{Research methods and design Design}

A quantitative and descriptive design was adopted for this survey since the purpose of the study was to describe the opinion of lecturers on plastinated specimens, their relevance (if any) in their various medical institutions and their likelihood of learning the technique. The descriptive profile (demography) of respondents and its correlation with other parameters of anatomical resource utilisation will also be highlighted in the context of the study. Quantitative analyses in this study will describe the knowledge and awareness of lecturers on the technique of plastination and, hence, provide insight into the need for greater advocacy for its introduction in medical schools based on feedback received.

\section{Materials and data collection methods}

Eighty-five questionnaires were distributed to lecturers at the conference of the Society of Experimental and Clinical Anatomists of Nigeria (SECAN). The questionnaire comprised of a list of closed-ended questions that also aimed at extracting specific details regarding the knowledge, awareness and use of other teaching aids for anatomy by the respondents. This approach was adopted to enable greater flexibility in the depth of questions and allow for enhanced interpretation of data generated. It was also possible to allow us to probe specific aspects pertaining to the issue of plastination and other preservation methods and make comparative evaluations as well.

The questions were designed to; get basic demographic data of participants, their educational status, use of teaching aids, and awareness of preservation techniques for cadavers, awareness of plastination with a comparison with other methods, as well as associated hazards. At the end of the programme, eighty respondents completed and returned the questionnaires, whilst five failed to return theirs.

\section{Data analysis}

All data from the questionnaires were entered into and analysed by the researchers using Microsoft Excel to produce frequency tables. This was independently done and cross checked by every team member to ensure accurate data input. A meeting was scheduled to reach consensus as to the specific format of presentation of data. Results have been presented in simple descriptive statistics.

\section{Context of study}

The study was carried out during the 10th Annual Conference of SECAN held at the ESUT auditorium, Enugu, South Eastern Nigeria from 24th to 26th March, 2011. The questionnaire was administered during the conference in order to ensure ample opportunity to have a large assemblage of teachers of anatomy from the various medical colleges across the country. The survey room (auditorium) was conducive for a research interview to be conducted.

\section{Results}

A $94.0 \%$ response rate was achieved. Analysis of the data showed that the bulk of staff were academics (lecturers and senior lecturers, constituting over $56.0 \%$ ) as against $5.0 \%$ of the professorial cadre. Of respondents sampled, $24.0 \%$ had obtained their PhD degrees, 50.0\% masters in Anatomy, and about $12.0 \%$ with various professional fellowships in different specialties of medical science (Table 1).

When asked if they have used any teaching aid or tool during their career, $76(96.0 \%)$ of the respondents said yes, whilst four $(4.0 \%)$ said no. Only about $9.0 \%$ of respondents utilise plastinates in their institutions, as against other teaching resources (plastic models $40.0 \%$, cadavers $36.0 \%$, and pathology pots $15.0 \%$ ) (Table 2 ).

TABLE 1: Demographic data of lecturers surveyed.

\begin{tabular}{|c|c|c|c|c|c|c|c|c|c|c|}
\hline \multirow[t]{2}{*}{ Rank } & \multicolumn{3}{|c|}{ Highest Qualification } & \multicolumn{3}{|c|}{ Area of lecture } & \multicolumn{4}{|c|}{ Experience } \\
\hline & $n$ & $\%$ & Description & $n$ & $\%$ & Description & $n$ & $\%$ & Years & Number \\
\hline Professor & 1 & 1.25 & $\mathrm{PhD}$ & 19 & 23.75 & $\begin{array}{l}\text { Basic medical sciences } \\
\text { (Anatomy) }\end{array}$ & 63 & 78.75 & $01-03$ & 30 \\
\hline Associate professor & 3 & 3.75 & Professional Fellowships & 10 & 12.5 & Clinical sciences & 7 & 8.75 & $04-06$ & 16 \\
\hline Senior Lecturer & 15 & 18.75 & Masters & 40 & 50 & Both & 10 & 12.5 & 07-09 & 4 \\
\hline Lecturer I & 23 & 28.75 & MBBS/MD & 6 & 7.5 & - & - & - & $10-12$ & 20 \\
\hline Lecturer II & 18 & 22.5 & BSc & 5 & 6.25 & - & - & - & $13-15$ & 10 \\
\hline Assistant lecturer & 11 & 13.75 & - & - & - & - & - & - & $>15$ & 0 \\
\hline Graduate assistant & 9 & 11.25 & - & - & - & - & - & - & - & - \\
\hline Total & 80 & - & - & 80 & - & - & 80 & - & - & 80 \\
\hline
\end{tabular}

$n$, number. 
TABLE 2: Teaching and learning aids utilised by respondents.

\begin{tabular}{llccc}
\hline Groups & Sub-group & \multicolumn{2}{c}{ Respondents } & \multirow{2}{*}{ Total (\%) } \\
\cline { 3 - 4 } & & $\boldsymbol{n}$ & $\mathbf{\%}$ & \\
\hline Learning/teaching & - Plastic models & 32 & 40 & \multirow{2}{*}{80} \\
aid utilised & - Cadavers & 29 & 36.25 & \\
& - Pathology pots & 12 & 15 & \\
Methods of & Plastinates & 7 & 8.5 & \\
preservation & - Immersion & 12 & 15 & \multirow{2}{*}{80} \\
& - Embalmment & 42 & 52.5 & \\
Reason for choice & - Both & 26 & 32.5 & \\
of method of & - Both & 20 & 25 & \multirow{2}{*}{80} \\
preservation & - Easy & 45 & 56.25 & \\
& - Only method & 10 & 12.50 & \\
& known & & & \\
\hline
\end{tabular}

n, number.

Seventy-five (93.75\%) of the respondents said they had heard about plastination before, whilst five $(6.25 \%)$ said there are not aware of it. Of the former $21(26.25 \%)$ had heard of the concept through conferences, 17 (21.25\%) (Colleagues), $21(26.25 \%)$ (Internet), 8 (10.0\%) (Used in institution) and 8 $(10.0 \%)$ (Other means like seminars, e-books). Twenty two respondents $(27.5 \%)$ had seen a plastinated specimen before, whilst $58(72.5 \%)$ had never seen a plastinated specimen. All respondents affirmed that the medical schools would benefit from the use of plastinates. Respondents' opinion about plastinates ranged from; 'it been a great resource', 'been realistic and commendable', and an 'excellent tool for teaching'. Others felt it should be used as a support tool to teaching, learning and examination (Table 3).

When asked if plastinates could replace cadavers $36(45.0 \%)$ agreed, 4 (5.0\%) did not, 40 (50.0\%) agreed with the proviso that it should be used alongside other tools for teaching. When asked if they would want to learn the technique of plastination, $68(85.0 \%)$ of respondents agreed whilst 12 $(15.0 \%)$ did not. When asked if plastinates were better than cadavers as a teaching tool, $32(40.0 \%)$ said yes, $28(35.0 \%)$ said no, whilst 20 (25.0\%) did not know.

\section{Ethical considerations}

Prior to the administration of the research instrument, the Department of Anatomy Postgraduate Ethical Committee, as well as the Faculty of Basic Sciences' Ethics Committee, University of Uyo, gave approval for the study. The study meets the national criteria of research conducted in an educational setting, involving instructional educational strategies for the advancement of new techniques for teaching and learning. It specifically falls under the criteria exempted from the health research ethics committee as there is no direct or indirect harm to respondents in the study.

\section{Informed consent}

The researcher made every effort to explain the purpose of this survey to the participants prior to administration of the research instrument. Participants were given an information sheet of informed consent for the study thereafter (which included information that this survey was purely voluntary).

\section{Data protection}

Anonymity was maintained as there were no means of identifying names or participants. All participants were fully informed that data gathered from this survey were purely for research purposes and would not be available to any third party. Outcome measures of this survey would be published in a peer-reviewed journal and accessible to participants as well.

\section{Validity and reliability}

This study has been advanced in the emerging and relevant aspect of plastination in anatomical sciences; the output (article) would be peer-reviewed by external experts and

TABLE 3: Grading of various aids and/or tools by respondents.

\begin{tabular}{|c|c|c|c|c|c|c|c|c|c|}
\hline \multirow[t]{3}{*}{ Aids } & \multirow[t]{3}{*}{ Grading } & \multicolumn{8}{|c|}{ Model for teaching and or learning } \\
\hline & & \multicolumn{2}{|c|}{ Wet specimens/Cadavers } & \multicolumn{2}{|c|}{ Plastic models } & \multicolumn{2}{|c|}{ Pathological pots } & \multicolumn{2}{|c|}{ Plastinated specimens } \\
\hline & & $n$ & $\%$ & $n$ & $\%$ & $n$ & $\%$ & $n$ & $\%$ \\
\hline \multirow{3}{*}{$\begin{array}{l}\text { Handle ability } \\
\text { of aid or tool }\end{array}$} & Favourable & 35 & 43.75 & 66 & 82.5 & 30 & 37.5 & 48 & 60 \\
\hline & Unfavourable & 35 & 43.75 & 4 & 5 & 12 & 15 & 0 & 0 \\
\hline & Don't know & 10 & 12.5 & 10 & 12.5 & 38 & 47.5 & 32 & 40 \\
\hline \multirow{3}{*}{$\begin{array}{l}\text { Suitability for } \\
\text { practical } \\
\text { examination }\end{array}$} & Favourable & 69 & 86.25 & 50 & 62.5 & 30 & 37.5 & 37 & 46.25 \\
\hline & Unfavourable & 11 & 13.75 & 12 & 15 & 10 & 12.5 & 3 & 3.75 \\
\hline & Don't know & 0 & 0 & 18 & 22.5 & 40 & 50 & 40 & 50 \\
\hline \multirow{3}{*}{$\begin{array}{l}\text { Cost of aid or } \\
\text { tool }\end{array}$} & Favourable & 50 & 62.5 & 25 & 31.25 & 12 & 15 & 8 & 10 \\
\hline & Unfavourable & 20 & 25 & 35 & 43.75 & 27 & 33.75 & 22 & 27.5 \\
\hline & Don't know & 10 & 12.5 & 20 & 25 & 41 & 51.25 & 50 & 62.5 \\
\hline \multirow{3}{*}{$\begin{array}{l}\text { Condition of } \\
\text { specimen/aid }\end{array}$} & Favourable & 38 & 47.5 & 50 & 62.5 & 30 & 37.5 & 32 & 40 \\
\hline & Unfavourable & 32 & 40 & 8 & 10 & 20 & 12.5 & 0 & 0 \\
\hline & Don't know & 10 & 12.5 & 22 & 27.5 & 40 & 50 & 48 & 60 \\
\hline \multirow{2}{*}{$\begin{array}{l}\text { Information } \\
\text { contained in } \\
\text { aid/specimen }\end{array}$} & Unfavourable & 8 & 10 & 10 & 12.5 & 10 & 12.5 & 2 & 2.5 \\
\hline & Don't know & 12 & 15 & 32 & 40 & 48 & 60 & 54 & 67.5 \\
\hline \multirow{3}{*}{$\begin{array}{l}\text { Realistic quality } \\
\text { of specimen/aid }\end{array}$} & Favourable & 45 & 56.25 & 36 & 45 & 28 & 35 & 39 & 48.75 \\
\hline & Unfavourable & 20 & 25 & 24 & 30 & 14 & 17.5 & 5 & 6.25 \\
\hline & Don't know & 15 & 18.75 & 20 & 25 & 38 & 47.5 & 36 & 45 \\
\hline
\end{tabular}

n, number. 
eventually published for reference by others. All literature sources and data, as well as materials utilised and represented by the authors in the paper, are credible, dependable and can be verified.

Validity for this study was achieved on the one hand, by the fact that the respondents were willing to complete the self-administered questionnaire. Research questions were specifically tailored to address the core aspects of the survey and researchers internally ensured that data generated from the instrument were cross-checked and a consensus reached by all team members. Inferential validity was also ensured throughout the study and the conclusions were inferred from the findings of the study. Reliability in this survey would be ascribed to the consistency and reproducibility of the research instrument used, which refers to the degree of accuracy.

\section{Discussion}

For more than 500 years the human cadaver has been utilised as a learning tool and traditionally, remains the pillar for the teaching and study of human anatomy (Parker 2002; Older 2004) across medical schools. However, in the wake of recent and evolving changes and adaptations by different medical institutions across the world, there is great divergence in the way anatomy has been taught. Consequently, discussions as to the quality of medical graduates with poor knowledge of anatomy have taken centre stage in the medical education arena (Bergman, Van der Vleuten\& Scherpbier 2011). In the midst of this downward spiral in teaching anatomy to undergraduates and medical graduates as part of their training (Older 2004), it has become even increasingly difficult to find a balance as to the best methods or tools to be adopted for this purpose, thus provoking lots of international debates. Plastination has come to be recognised as a technique for direct or indirect instructional method (Pashaei 2010). Various authors have affirmed that the plastination technique has led to the production of a wide range of anatomical specimens for teaching (De Barros et al. 2001; Reidenberg \& Laitman 2002) across diverse areas of anatomy, pathology, veterinary medicine, archaeology and radiology ( $\mathrm{Nel} 1997)$.

From our survey, plastination as a method of preservation is yet to become fully integrated as a teaching aid in most of the medical colleges in Nigeria, this, despite the high level of awareness amongst lecturers of this technique albeit via colleagues, conferences and the internet. Many still have never really seen a plastinated specimen before, but express a desire to learn about it. This is an encouraging development that indicates a need for support in funding the setting up of a plastination laboratory and the subsequent production of plastinates and their use as an additional teaching aid in anatomy for medical schools.

In the last two decades following the invention of plastination, new vistas have opened up in gross anatomy leading to major expansion in the range of human anatomic specimens available for teaching and its potential value in research (Jones 2002). More recently, it has also become a public issue through what has become known as 'Anatomy Art', as depicted in Von Hagens' exhibition, Korperwelten (Bodyworlds). The exhibition in Mannheim received over 800000 visitors and even more were recorded when it was held in Japan, Vienna and Cologne (KC et al. 2007).

Our study has equally shown that in most of the medical colleges, preservation of tissues have been largely by embalmment and immersion fixation using formalin solution because this method is cheap and easy to use. This is despite the associated hazards implicated following exposure to formaldehyde, including allergic dermatitis, ocular and airway disorders and carcinogenesis (Akbar-Khanzadeh et al. 1994). Our results are similar to what was obtained in the study of Peris (2000). As a follow-up on this, we suggest the introduction of plastination and plastinated specimens to address this issue and prevent excessive exposure of staff and students to the toxic substances used in embalming fluids.

In this study, we corroborated other reports which buttressed that plastinated specimens, as a teaching resource, should be used to complement the dissection experience of students (Parker 2002, Reeves et al. 2004); although some authors believe plastinates should completely replace dissection experience (Reidenberg \& Laitman 2002; McLachlan et al. 2004). The general acceptability of plastination as a necessary anatomical tool by teachers of anatomy in the various medical schools sampled also agrees with our previous studies, which showed that medical students where strongly in support of the introduction of plastinated specimens to complement cadaveric materials and introduce a new dimension to anatomical study (Azu et al. 2012).

Whilst plastination technology is still a new concept in many medical institutions in Africa, the gradual but tenacious influence of technological transfer and expertise across the globe is creating a strong force that will eventually instill the establishment of veritable plastination laboratories across the medical schools. With the influence of workshops and technical support from the International Society for Plastination (ISP), which is the umbrella body and pioneers for plastination, it is envisaged that more expertise would be needed to fully explore this virgin aspect of anatomical resource.

\section{Limitations of the study}

We are aware that there is a dearth of anatomist or teachers of anatomy across the medical colleges in Nigeria; hence, a major limitation of this survey was a limited number of anatomists that filled the questionnaires. However, the total number of lecturers that attended SECAN reflects all the medical colleges across the regions of the country, therefore shared the diverse interests as well that would possibly be captured. 


\section{Recommendations}

Based on the findings of this study, it is recommended that there is the need for commencement of use of plastinates to complement cadaveric materials at the various anatomy departments in the country. With the positive enthusiasm and interest shown by lecturers towards advancing their training in plastination, it is advocated that more hands-on workshops and courses be organised to boost the human capacity development in this aspect in affiliation with counterparts from Europe and America.

\section{Conclusion}

As plastination science gradually enters the domain as an additional resource in departments of anatomy in medical colleges, teachers in anatomy are yet again provided with another vista for exploring their teaching and research skills in the various aspects of anthropology, developmental anatomy, gross anatomy and other comparative studies, which this technique would stimulate. This survey is expected to further stimulate advocacy and attract the needed funding from the various institutional managers and administrators to look at the direction and to free up the unnecessary pressure already created by cadaveric material shortage in many institutions.

\section{Acknowledgements Competing interests}

All authors declare that they have no financial or personal relationship(s), which may have influenced them inappropriately in writing this article.

\section{Author contributions}

This article was based on the research conducted by O.O.A. The design was formulated by O.O.A. and A.I.P. A.N.A. took part in the data collection and analysis while O.O.A., A.I.P., A.N.A. and G.J.E. contributed to the final draft of the article. O.O.A. was responsible for all correspondence regarding submission.

\section{References}

Akbar-Khanzadeh, F.M., Vaquerano, M.U., Akbar-Khanzadeh, M. \& Bisesi, M.S.,1994 'Formaldehyde exposure, acute pulmonary response and exposure control options in a gross anatomy laboratory', American Journal of Industrial Medicine 26, 61-75. http://dx.doi.org/10.1002/ajim.4700260106

Azu, O.O., Peter A.I., Etuknwa, B.T. \& Ekandem, G.J., 2012, 'The Awareness of Medical Students in Nigerian Universities about the Use of Plastinated Specimens for Students in Nigerian Universities about the Use of Plastinated Specimens for Anatomical Studies', Macedonian Journal of Medicd
dx.doi.org/10.3889/MJMS.1857-5773.2011.0202

Azu, O.O. \& Osinubi, A.A.A., 2011, 'A survey of problem-based learning and traditional methods of teaching anatomy to 200 level pharmacy students of the Faculty of Pharmacy, University of Lagos, Nigeria', African Journal of Pharmacy and Pharmacology 5(2), 219-224.

Bergman, E.M., Van der Vleuten, C.P.M. \& Scherpbier, J.J.A., 2011, 'Why don't they know enough about anatomy? A narrative review', Medical Teacher 33, 403-409. http://dx.doi.org/10.3109/0142159X.2010.536276

De Barros, N., Junqueira, R.C., Junqueira, R.A., De Germano, M.A., Guido, C.G., 2001, 'The value of teaching sectional anatomy to improve CT scan interpretation', Clinical CA1006>3.0.CO;2-G

Horst-Werner, K., Wicht, H., Snipes, R.L., Timmermans, J., Paulsend, F., Runee, G. \& Baumgart-Vogt, E., 2008, 'The dissection course - necessary and indispensable for teaching anatomy to medical students', Annals of Anatomy 190, 16-22. http:// dx.doi.org/10.1016/j.aanat.2007.10.001

Henry, G., 1918, 'Anatomy of the Human Body', 20th edn., viewed 27 March 2007, from http://www.bartleby.com/107/1.html

Jones, D.G., 2002, Re-inventing anatomy: The impact of plastination on how we see the human body', Clinical Anatomy 15(6), 436-440. http://dx.doi.org/10.1002/ ca. 10040

KC, N., Priya, K., Lama, S. \& Magar, A., 2007, 'Plastination-an unrevealed art in the medical science', Kathmandu University Medical Journal 5(17), 139-141.

Latorre, R.M., Mari, P., 'a-Sanz, G., Moreno, M., Herna'ndez, F., Gil, F., Lo'pez, O., Ayala, M.D., Ramı 'rez, G., Va'zquez, J.M., Arencibia, A. \& Henry R.W., 2007, 'Research and Education Reports. How Useful Is Plastination in Learning Anatomy?', Journa of Veterinary Medical Education 34(2), 172-176. http://dx.doi.org/10.3138/ jvme.34.2.172

McLachlan, J.C., Bligh, J., Bradley, P. \& Searl, J., 2004, 'Teaching anatomy without cadavers', Med Educ 38, 418-424. http://dx.doi.org/10.1046/j.1365-2923. 2004.01795.x

Nel, P.P.C., 1997, 'Research applications of plastination', The International Society for Plastination 12(1), 9-12.

Older, J., 2004, 'Anatomy: A must for teaching the next generation', Surgeon-journal of The Royal Colleges of Surgeons of Edinburgh and Ireland 2, 79-90. http://dx.doi. org/10.1016/S1479-666X(04)80050-7

Parker, L.M., 2002, 'Anatomical dissection: why are we cutting it out? Dissection in undergraduate teaching', Australian and New Zealand Journal of Surgery 72, 910912. http://dx.doi.org/10.1046/j.1445-2197.2002.02596.x

Pashaei, S., 2010, 'A brief rview on the history, methods and applications of plastination', International Journal of Morphology 28(4), 1075-1079.

Peris, K.J., 2000, 'Plastination Technology for Biomedical Research and Studies in Kenya', JISP 15(1) June.

Reeves, R.E., Aschenbrenner, J.E., Wordinger, R.J., Rogue, R.S. \& Sheedlo, H.J., 2004 Improved dissection experience in the human gross anatomy laboratory by the intergration of computers and modern technology', Clinical Anatomy 17, 337344. http://dx.doi.org/10.1002/ca.10245

Reidenberg, J.S. \& Laitman, J.T., 2002, 'The new face of gross anatomy', Anatomical Record 269(2), 81-88. http://dx.doi.org/10.1002/ar.10076

Saeed, M., Amin, A.R. \& Saleh E.E., 2001, 'Mummification to plastination', Saudi Medical Journal 22(11), 956-959.

Sugand, K., Abrahams, P. \& Khurana, A., 2010, 'The Anatomy of Anatomy: A Review for Its Modernization', Anatomical Sciences Education 3, 83-93.

Von Hagens, G., 1979, 'Impregnation of soft tissue biological specimens with thermosetting resins and elastomers', Anatomical Record 194, 247-255. http:// dx.doi.org/10.1002/ar.1091940206 